\title{
Effect of supplementation of rumen protected methionine and lysine on some physiological aspects of fattening calves
}

\author{
H.N. Maty \\ Department of Physiology, Biochemistry and Pharmacology, College of Veterinary Medicine, University of Mosul, Iraq
}

\begin{tabular}{l} 
Article information \\
\hline Article history: \\
Received January 23, 2020 \\
Accepted April 28, 2020 \\
Available online November 1,2020 \\
\hline Keywords: \\
Protected methionine \\
Protected lysine \\
Fattening calves \\
WBCs \\
RBCs \\
\hline Correspondence: \\
H.N. Maty \\
hemyatem@yahoo.com
\end{tabular}

\begin{abstract}
This study was carried out during the period from February-April 2019 at a private breeding field. A total of 82 imported calves for fattening 9-12 month of age. These calves were divided randomly into 3 groups and treated for 90 days as follows: G1 (27 calves) supplied with basal diet only and considered as control group, Calves of G2 (27 calves) of were supplied with basal diet complemented with RPM in complete feed using 15 g/animal/day, while G3 (28 calves) was supplied with basal diet complemented with RPL with $10 \mathrm{~g} / \mathrm{animal} / \mathrm{day}$. The results showed a significant increase in growth hormone value in the G2 in comparison with G1 and G3 at 90 day post treatment. While the mean values of body weight were $(310.8 \pm 12.97)$ and $(334.3 \pm 15.41)$ in $\mathrm{G} 2$ at 60 and 90 days respectively with significance deference in compare with G1and G3 $(p \leq 0.05)$. The significant increase in red blood cells count (RBCs) showed in G2, while the White Blood Cells (WBCs) increased in G1 when compare between groups. In addition, the results showed a significant increase $(\mathrm{p}<0.05)$ in cholesterol and triglycerides values in $\mathrm{G} 2$ in compare with G1 and G3. While no significant changes in total protein values revealed between groups. The results of this study confirmed that supplementation of RPM has the potential to improve body weight in fattening calves with enhancement of immune status of animals and an enhancement of oxygen flow to the tissues by increasing of RBCs counts especially with RPM, but lasser effects with RPL.
\end{abstract}

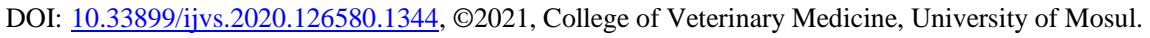

This is an open access article under the CC BY 4.0 license (http://creativecommons.org/licenses/by/4.0/).

\section{Introduction}

Fattening calves plays a crucial role in Iraqi market and most of these calves are kept by smallholder farmers, in latest years, demand for beef is growing. Livestock and poultry products are presently of two main kinds of meat resources and the major kinds of livestock in world are beef cattle, chicken, swine, dairy cows, and buffalo (1). Amino acids are the building parts of polypeptides and proteins that are the main elements of animals' muscles and tissues, these amino acids also form an essential unit in some fluids such as milk and play a significant role in many principle biochemical and metabolic events within the animal cells (2). The protein-producing ability of an animal is restricted by the quantities of amino acids within its body. Later some proteins require specific amino acids, if the body cannot create sufficient amount of a single amino acid or it is not supplemented in sufficient amount in the food (3). One vital Amino acid that could possibly be restraining for reproduction in lactating dairy cows is methionine (Met) (4). Preceding studies that assessed the effects of consuming rumen-protected methionine (RPM) on milk production recognized a reliable improve in milk protein profit and in general milk protein yield in high producing dairy cows $(5,6)$ as well as improving the reproductive performance in animals (7) and has a similar effect to other many essential amino acids like arginine supplementation for ruminants (8). Supplementation of rumen protected methionine is helpful for developing of the Performance of calves weight gain and efficiency of feed utilization (9). 
Lysine (Lys) is one of fundamental amino acid required for the synthesis of protein in growth, milk production, tissue healing and gestation (10). Lys is cited as the mostlimiting amino acid in feed thus Supplementation of rumenprotected Lys (RPL) could be helpful if Lys is limiting in diets (11). Met and Lys Are the $1^{\text {st }}$ limiting amino acids in microbial protein. If specific amino acids are limiting, complementing cattle with bypass protein has been shown to increase gains and feed efficacy especially for young and fast growing calves (12). Met/lys supplementation lead to elevate in protein scores, water keeping capacity and lesser shear force marks (13) Thus, protecting the amino acids from ruminal degradation has made it achievable to supplement diets with particular amino acids that will become obtainable directly for absorption in intestine (14). Therefore, due to the few studies that evaluate of Met and Lys supplementation as a ruminal protected amino acid in fattening animals, the present study aimed to evaluate the influence of daily providing coated Met and Lys in mixture protein sources based diets on growth performance, blood parameters, serum biochemical indices of fattening calves.

\section{Material and methods}

\section{Animals and experimental design}

This study was carried out during the period from February-April 2019 at private breeding field located at Bartella district, Mosul, Iraq. A total of 82 imported calves for fattening 9-12 month of age. Calves were housed in separated pens $(18 \times 20$ meter). Clean drinking water $a d$ libitum throughout the fattening period ( 3 month). The constituent and nutrient levels of the basal diet recommendation National Research Council (14). All calves were kept under standard hygienic circumstances. Both (MetiPEARL) ${ }^{\circledR}$ : Rumen Protected Methionine Consist of protected or encapsulated D-L methionine (3c301) 550 $\mathrm{g} / \mathrm{kg}$ and LysiGEM) ${ }^{\circledR}$ : Rumen Protected Lysine Consist of protected or encapsulated L-lysine monohydrochloride (3.2.3.) $680 \mathrm{~g} / \mathrm{kg}$ (Packing $25 \mathrm{~kg}$ bags separately) were homogenates with the feed prior to its providing for each group. Calves were divided randomly into 3 groups and treated for 90 days as follows: G1 (27 calves) supplied with basal diet only and considered as control group. Calves of G2 (27 calves) of were supplied with basal diet complemented with (MetiPEARL) ${ }^{\circledR}$ Mix carefully in complete feed using $15 \mathrm{~g} / \mathrm{animal} / \mathrm{day}$, while G3 (28 calves) was supplied with basal diet complemented with $\left(\right.$ LysiGEM) ${ }^{\circledR}$ with10 g/animal/day (Table 1).

\section{Data collection}

The primary and final body weight $(\mathrm{kg})$ was recorded monthly. Blood samples were collected from jugular vein at 90 days post supplementation and each samples were divided into two parts one for measuring the complete blood picture and another for serum collection. The sera were separated at $3000 \mathrm{rpm}$ by centrifugation for 15 minutes. Sera were stored at $-20^{\circ} \mathrm{C}$ until further processing. The parameters analyzed in sera include: total protein, cholesterol and triglyceride using commercial kits (Biolabo, France) and growth hormone measured using bovine GH ELISA kit. Data were expressed as mea \pm SE and analyzed by using of one - way analysis of variance (ANOVA). The significance of differences between means was tested by Duncan multiple range test at $\mathrm{P}<0.05$ (15).

Table 1: Ingredient and chemical composition of basal diets

\begin{tabular}{lccc}
\hline \multirow{2}{*}{ Item } & \multicolumn{3}{c}{ Groups (DM\%) } \\
\cline { 2 - 4 } & First & Second & Third \\
\hline Corn 7.5\% & 10 & 10 & 10 \\
Barley 10\% CP & 20 & 20 & 20 \\
Wheat bran 13.5\% & 17.3 & 17.3 & 17.3 \\
Wheat hard 12\% & 23.0 & 23.0 & 23.0 \\
Soya bean meal 47\% & 13.8 & 13.8 & 13.8 \\
Wheat flour 12\% & 10 & 10 & 10 \\
Soya oil & 1.0 & 1.0 & 1.0 \\
Premix & 2.5 & 2.5 & 2.5 \\
Lime stone & 0.25 & 0.25 & 0.25 \\
Salt & 0.65 & 0.65 & 0.65 \\
dicalcium Phosphate & 1.25 & 1.25 & 1.25 \\
Sodium bicarbonate & 0.25 & 0.25 & 0.25 \\
\hline Nutrient composition & & & \\
\hline Dry matter DM & 86.92 & 86.92 & 86.92 \\
Crude protein CP & 15.5 & 15.5 & 15.5 \\
Metabolic energy & 2726 & 2726 & 2726 \\
Crude fat CF & 3.06 & 3.06 & 3.06 \\
Fiber & 4.9 & 4.9 & 4.9 \\
Ash & 5.2 & 5.2 & 5.2 \\
Acid detergent fiber & 6.47 & 6.47 & 6.47 \\
Neutral detergent fiber & 13.83 & 13.83 & 13.83 \\
Starch & 39.6 & 39.6 & 39.6 \\
Hemicellulose & 2.49 & 2.49 & 2.49 \\
Total digestible nutrient & 71.8 & 71.8 & 71.8 \\
RPM (g/animal) & - & 15 & - \\
RPL (g/ animal) & - & - & 10 \\
\hline
\end{tabular}

\section{Results}

The results in table 2 revealed a significant increase of growth hormone value in the G2 in comparison with G1 at 90 day post treatment. The mean values of body weight showed no significant differences between groups at 30 day post treatment, While, a significant increase in the mean values of body weight were reported in G2 received RPM at 60 and 90 days of the treatment as compared to the control group. The mean values were $310.8 \pm 12.97$ and $334.3 \pm 15.41$ in $\mathrm{G} 2$ at 60 and 90 days respectively (Table 2).

The significant increase in red blood cells count (RBCs) showed in G2, while the White Blood Cells (WBCs) reveled significant decrease in G2 when we compare with G1. There were no significant differences detected in lymphocytes, Hemoglobin (HGB), Hematocrit (HCT), 
Mean corpuscular volume (MCV), mean corpuscular hemoglobin $(\mathrm{MCH})$, mean corpuscular hemoglobin concentration (MCHC), Platelets (PLT) and Red cell distribution width RDW between the groups (Table 3).
The results of biochemical parameters showed significant increase in cholesterol and triglycerides values in G2 in compare with G1. While no significant changes in total protein values revealed between groups (Table 4).

Table 2: Effect of RPM and RPL on growth hormone and body weight

\begin{tabular}{lccccc}
\hline \multirow{2}{*}{ Groups } & GH ng/ml after 90 & \multicolumn{4}{c}{ Mean of body weight $(\mathrm{kg}) \pm$ St. error } \\
\cline { 3 - 6 } & days post treatment & 0 day & 30 day & 60 day & 90 day \\
\hline G1 (control) & $7.8 \pm 0.33 \mathrm{~b}$ & $247.2 \pm 18.13 \mathrm{a}$ & $260.4 \pm 8.7 \mathrm{a}$ & $279.9 \pm 8.2 \mathrm{~b}$ & $301 \pm 10.8 \mathrm{~b}$ \\
G2 (MetiPEARL) & $19.3 \pm 0.46 \mathrm{a}$ & $259 \pm 20.27 \mathrm{a}$ & $279.8 \pm 10.6 \mathrm{a}$ & $310.8 \pm 12.97 \mathrm{a}$ & $334.3 \pm 15.41 \mathrm{a}$ \\
G3 (LysiGEM) & $7.4 \pm 1.06 \mathrm{~b}$ & $246.8 \pm 7.7 \mathrm{a}$ & $262.2 \pm 8.7 \mathrm{a}$ & $284 \pm 7.2 \mathrm{ab}$ & $312.4 \pm 12.03 \mathrm{ab}$ \\
\hline
\end{tabular}

The different superscript in each column means statistically different significantly at $\mathrm{P}<0.05$.

Table 3: Effect of RPM and RPL on some blood parameters

\begin{tabular}{lccc}
\hline \multirow{2}{*}{ Parameters } & \multicolumn{3}{c}{ Groups } \\
\cline { 2 - 4 } & $\begin{array}{c}\text { G1 } \\
\text { (control) }\end{array}$ & $\begin{array}{c}\text { G2 } \\
(\text { MetiPEARL }\end{array}$ & $\begin{array}{c}\text { G3 } \\
(\text { LysiGEM) }\end{array}$ \\
\hline WBCs & $15.06 \pm 0.7 \mathrm{a}$ & $11 \pm 1.2 \mathrm{~b}$ & $13.06 \pm 1.24 \mathrm{ab}$ \\
Lymphocytes & $8.12 \pm 0.4 \mathrm{a}$ & $7.6 \pm 0.8 \mathrm{a}$ & $8.6 \pm 1.19 \mathrm{a}$ \\
RBCs & $6.09 \pm 0.39 \mathrm{c}$ & $8.61 \pm 0.45 \mathrm{a}$ & $7.48 \pm 0.17 \mathrm{~b}$ \\
HGB & $90.4 \pm 8.51 \mathrm{a}$ & $107.6 \pm 3.6 \mathrm{a}$ & $94.8 \pm 2.39 \mathrm{a}$ \\
HCT & $40.9 \pm 3.99 \mathrm{a}$ & $44.7 \pm 1.2 \mathrm{a}$ & $40.1 \pm 1.34 \mathrm{a}$ \\
MCV & $52.8 \pm 1.6 \mathrm{a}$ & $52.5 \pm 2.65 \mathrm{a}$ & $53.6 \pm 1.21 \mathrm{a}$ \\
MCH & $12.8 \pm 0.25 \mathrm{a}$ & $12.2 \pm 0.67 \mathrm{a}$ & $12.6 \pm 0.12 \mathrm{a}$ \\
MCHC & $235.4 \pm 2.1 \mathrm{a}$ & $234 \pm 2.25 \mathrm{a}$ & $236.4 \pm 3.2 \mathrm{a}$ \\
PLT & $196.6 \pm 35 \mathrm{a}$ & $296.8 \pm 94 \mathrm{a}$ & $422 \pm 880.9 \mathrm{a}$ \\
RDW & $17.4 \pm 0.6 \mathrm{a}$ & $19.4 \pm 0.21 \mathrm{a}$ & $19.1 \pm 1.1 \mathrm{a}$ \\
\hline
\end{tabular}

The different superscript in each column means statistically different significantly at $\mathrm{P}<0.05$.

Table 4: Effect of RPM and RPL on some biochemical parameters

\begin{tabular}{lccc}
\hline Groups & \multicolumn{3}{c}{ Biochemical values after 90 day post } \\
& \multicolumn{3}{c}{ treatment } \\
\cline { 2 - 4 } & total protein & cholesterol & triglycerides \\
\hline G1 (control) & $7.08 \pm 0.1 \mathrm{a}$ & $66 \pm 3.14 \mathrm{~b}$ & $20.8 \pm 1.01 \mathrm{~b}$ \\
G2 (MetiPEARL) & $7.16 \pm 0.2 \mathrm{a}$ & $94.2 \pm 5.8 \mathrm{a}$ & $36.8 \pm 2.76 \mathrm{a}$ \\
G3 (LysiGEM) & $7.14 \pm 0.13 \mathrm{a}$ & $66.4 \pm 3.07 \mathrm{~b}$ & $21.6 \pm 0.74 \mathrm{~b}$ \\
\hline
\end{tabular}

The different superscript in each column means statistically different significantly at $\mathrm{P}<0.05$.

\section{Discussion}

Free methionine and lysine undergo degradation in the rumen; coating of these amino acids is one way to protect it from this degradation in rumen and comes obtainable in the small intestine for absorption. Innovate unique coating procedure is based on advanced technology. This technique ensures that the maximum amount of covered nutrients is able to bypass rumen fermentation and stay available at the small intestine (16).
The results of significant increasing of body weight of G2 in compare with G1 and G3 agreed with Singh et al. (17) when they studied the effect the same products in heifers, but not agreed with Lopes et al. (18) suggesting that the response of increasing of body weight was due to lysine, not methionine (treated group with a mixture of Met+Lys), although non significance increasing of body weight in G1 to G2 occur as a result of dietary protein supplementation that are respected to be beneficial resources of "bypass" or rumen non degradable protein have been used in expansion of animal performance (19), and Dietary supplementation of rumen protected protein and amino acids are suggested to keep the physiological and productive requirements of livestock for amino acids (11), while this results agreed with one study that evaluated the effect of supplementing crossbred steers with rumen protected methionine, rumen protected lysine or a mixture of both rumen protected amino acid through the entire feeding interval 134day (20).

The varied results of growth hormone $(\mathrm{GH})$ is due to the restrictions in Methionine reduce the capability of GH to promote insulin like growth factor one (IGF1) production (21). The decrease in receptor expression of GH in the liver of peri-partal cows is a single cause that accounts for decrease of messenger RNA expression and blood quantity of IGF1, mainly after calving (22), or the Diverse in results of growth hormone because the various in dry matter intake and this remarks is matched with Trinacty et al. (23) when they declared that entire dry matter intake (DMI) was lesser in control than Rumen protected lysine group and Rumen protected methionine group. Changes in DMI resulted in notably superior intake of other nutrients (crud protein, fat) in which may led to significant increase of body weight with (MetiPEARL)®, or there is established an elevation the level of plasma GH in early lactating ruminants triggers metabolic alterations in liver, skeletal muscle and adipose tissue (24) thus this metabolic alteration may perform a role in the increasing the level of this hormone in G2.

Normal physiology and pathology of the bovine blood picture were examined. The results of a complete blood count $(\mathrm{CBC})$ calculation are usually beneficial in the monitoring, diagnosis and prediction of an illness. If computerized cell counts are utilized to achieve a CBC, 
results should be understood with carefully to avert false +ve or false -ve results (25). An increasing of WBCs counts in G1 in comparison with G2 and G3 agreed with study that well proven that metabolic outcomes of Met metabolism perform a crucial function as a preservative and supportive ingredients for immunity, and this effect of RPM may lead to decrease the infections with different microbes $(26,6)$. The immune-modulator effects of these metabolites are featured by the decline in lymphocyte count and phagocytic process during taurine metabolite deficiency as well as an increase in Polymorph nuclear cell attachment when homocysteine metabolite concentration mounted (27).

The counting of RBCs in this study disagreed with Blum et al. (28) that mentioned no significant change in RBCs counts when it measured at 68 day post treatment with protected methionine, while other the values of other parameters including MCV, RDW, hemoglobin, platelets and hematocrit agreed with Roland et al. (25).

The total protein values in this study was not significantly affected $(28,29)$. While increased total cholesterol in G2 is due to glucagon increase and this will lead glucose yield from the liver and drops insulinglucagon fraction, increase plasma glucose $(30,28)$ and ultimately to rise the concentration of HDL2-cholesteryl ester and LDL-free cholesterol in plasma (31). The rumen protected methionine might have an effect on the endocrine system, leading to possible expand in growth hormone and glucagon, thus the increase in entire cholesterol in our experts might have been produced by GH (28).

Triglycerides value was elevated significantly in G2 and this results agreed with (30) that mentioned to increasing the levels of plasma triglycerides and very low density lipoproteins were higher in treated group with methionine and lysine at $(\mathrm{P}<0.01)$ in compare with control group, this results is due to decrease in plasma NEFA (non-esterified fatty acid) levels suggested that there was esterification of NEFA into triglycerides and VLDL which might have been used as energy sources in the body (32).

\section{Conclusion}

It can have concluded that the dietary protected methionine improved the body weight and RBCs count, furthermore fattening calves fed on RPM had higher cholesterol and triglycerides. Methionine is required in the diet in the rumen protected form to enhance the immune status in fattening calves.

\section{Acknowledgments}

The author thankfully acknowledges the College of Veterinary Medicine, University of Mosul, and Kemin Industries, Middle East (Jordan-Iraq) for support of this research with protected amino acids. Finally, many thanks to the owner of the animals.

\section{Conflict of Interest}

The author declares that there is no conflict of interest.

\section{References}

1. Bunmee T, Chaiwang N, Kaewkot C, Jaturasitha S. Current situation and future prospects for beef production in Thailand: A review. Asian-Australasian J Anim Sci. 2018;31(7):968-975. Doi: https://doi.org/10.5713/ajas.18.0201

2. Wu G, Bazer FW, Dai Z, Li D, Wang J, Wu Z. Amino Acid Nutrition in Animals: Protein Synthesis and Beyond. Annu Rev Anim Biosci. 2014;2:387-417. 10.1146/annurev-animal-022513-114113

3. Górska-Warsewicz H, Laskowski W, Kulykovets O, KudlińskaChylak A, Czeczotko M, Rejman K. Food products as sources of protein and amino acids. Case Poland Nut. 2018;10(1):1977. Doi: 10.3390/nu10121977

4. Brosnan JT, Brosnan ME, Bertolo RFP, Brunton JA. Methionine: A metabolically unique amino acid. Livest Sci. 2007;112(1-2):2-7. https://DOI.org/10.1016/j.livsci.2007.07.005

5. Patton RA. Effect of rumen-protected methionine on feed intake, milk production, true milk protein concentration, and true milk protein yield, and the factors that influence these effects: A meta-analysis. J Dairy Sci. 2010;93:2105-2118. https://DOI.org/10.3168/jds.20092693

6. Ratika K, James Singh RK, Dahiya SS. Methionine, Lysine and Choline in Dairy Cows: A review article. Int J Curr Microbiol App Sci. https://DOI.org/10.20546/ijcmas.2018.707.456 2018;7(7):3921-3934.

7. Kassim HW, Almallah OD Abdulrahman SY. Effect of protected methionine and lysine supplementation to Awassi ewes ration at flushing period on productive performance. Iraqi $\mathrm{J}$ Vet Sci. 2019;23(2):105-109. Doi 10.33899/ijvs.2019.163174

8. Mohammed TR, Al-Ani AA, Munther AA. Effect of arginine on physiological and reproductive performance of Awassi ewes. Iraqi J Vet Sci. 2019;33(2):213-220. DOI: 10.33899/ijvs.2019.162878

9. Gavade VS, Gadegaonkar GM, Ramteke BN, Pagdhuneand AG, Kanduri AB. Effect of supplementation of rumen protected methionine and lysine in crossbred calves. Inter $\mathrm{J}$ Livestock Res. 2019;4(19):182-188.DOI: 10.5455/ijlr.20181223054332

10. Rebouche CJ, Seim H. Carnitine metabolism and its regulation in microorganisms and mammals. Ann Rev Nutrit. 1998;18:39-61. http://dx.DOI.org/10.1146/annurev.nutr.18.1.39

11. Paz HA, De Veth MJ, Ordway RS, Kononoff PJ. Evaluation of rumen protected lysine supplementation to lactating dairy cow consuming increasing amounts of distillers dried grains with solubles. J Dairy Sci. 2013;96:7210-7222. http://dx.DOI.org/10.3168/jds.2013-6906

12. Erickson PS, Kalscheur KF. Nutrition and feeding of dairy cattle. Anim Agricul. 2020:157-180. doi: 10.1016/B978-0-12-8170526.00009-4

13. Barido FH, Utama DT, Jeong HS, Kim J, Lee CW, Park YS, Lee SK. The effect of finishing diet supplemented with methionine/lysine and methionine/ $\alpha$ tocopherol on performance, carcass traits and meat quality of Hanwoo steers. Asian-Australas J Anim Sci. 2020;33:1:6978. DOI.org/10.5713/ajas.19.0209

14. National Research Council (NRC). 2001. Nutrient requirements of dairy cattle, $7^{\text {th }}$ edition.

15. Steel RGD, Torrie JH, Dickey DA. Principles and Procedures of Statistics: A Biometrical Approach. $3^{\text {rd }}$ ed. New York: McGraw-Hill Book Co; 1997. DOI: 10.4236/blr.2014.54024

16. Weekes TL, Luimes PH, Cant JP. Responses to amino acid imbalances and deficiencies in lactating dairy cows. J Dairy Sci. 2006; 89, 2177-2187. https://DOI.org/10.3168/jds.S0022-0302(06)72288-3

17. Singh JK, Roy D, Kumar VKM, Sirohi R. Effect of supplementing rumen protected methionine and lysine on nutrient intake and growth performance of Hariana heifers. Indian J. Dairy Sci. 2015;68(6). DOI:10.5146/ijds.v68i6.45811.g22995. 
18. Lopes MG, Dominguez JHE, Corrêa MN, Schmitt E, G Fischer G. Rumen-protected methionine in cattle: Influences on reproduction, immune response, and productive performance. Arq Inst Biol. 2019:86. DOI: 10.1590/1808-1657001292018

19. Tandon M, Siddique RA, Ambwani T. Role of bypass proteins in Ruminant production. Dairy Planner. 2008:4. 10: 11-14. DOI: 10.13140/RG.2.2.16615.04003

20. Hosford A, Hergenreder JE, Kim JK, Baggerman JO, Ribeiro FR, Anderson MJ, Spivey KS, Rounds W, Johnson BJ. Effects of supplemental lysine and methionine with zilpaterol hydrochloride on feedlot performance, carcass merit, and skeletal muscle fiber characteristics in finishing feedlot cattle. J Anim Sci. 2015;93:45324544. DOI: 10.2527 /jas.2015-9047

21. Stubbs AK, Wheelhouse NM, Lomax MA, Hazlerigg DG. Nutrienthormone interaction in the ovine liver: Methionine supply selectively modulates growth hormone-induced IGF-I gene expression. J Endocrinol. 2002;174:335-341. DOI: 10.1677/joe.0.1740335

22. Radcliff RP, McCormack BL, Crooker BA, Lucy MC. Plasma hormones and expression of growth hormone receptor and insulin-like growth factor-I mRNA in hepatic tissue of periparturient dairy cows. $\mathbf{J}$ Dairy Sci. 2003;86:3920-3926. DOI: $10.3168 /$ jds.S00220302(03)74000-4

23. Třinacty J, Křížová L, Hadrová $\mathrm{S}$, Hanuš $\mathrm{O}$, Janštová $\mathrm{B}$, Vorlová L, Dračková M. Effect of rumen-protected protein supplemented with three amino acids on milk yield, composition and fatty acid profile in dairy cows. J Anim Feed Sci. 2006;15(1):3-15. DOI: https://doi.org/10.22358/jafs/66834/2006

24. Giallongo F, Harper MT, Oh J, Lopes JC, Lapierre H, Patton RA, Parys C, Shinzato I, Hristov A.N. Effects of rumen-protected methionine, lysine, and histidine on lactation performance of dairy cows. J. Dairy Sci. 2016;99:4437-4452. doi.org/10.3168/jds.201510822

25. Roland L, Drillich M, Iwersen M. Hematology as a diagnostic tool in bovine medicine. J Vet Diagnost Invest. 2014;26(5): 592-598. DOI: 10.1177/1040638714546490

26. Grimble RF. Sulphur amino acids and the metabolic response to cytokines. Adv Exp Med Biol. 1994;359:41-9. DOI: 10.1007/978-14899-1471-2_5

27. Dudman NPB, Temple SE, Guo XW, Fu W, Perry MA. Homocysteine enhances neutrophil-endothelial interactions in both cultured human cell and rats in vivo. Circ Res. 1999;84:409-16. DOI: 10.1161/01.res.84.4.409

28. Blum JW, Bruckmaier RM, Jans F. Rumen-protected methionine fed to dairy cows: Bioavailability and effects on plasma amino acid pattern and plasma metabolite and insulin concentrations. J Dairy Sci. 1999;82:9. doi.org/10.3168/jds.S0022-0302(99)75435-4

29. Movaliya JK, Dutta KS, Padodara RJ, Bhadaniya AR, Savsani HH. Effect of bypass methionine-lysine supplementation on haematological and blood biochemical parameters of jaffarabadi heifers. Vet World. 2013;147-150. DOI: 10.5455/vetworld.2013.147150

30. Ganong WF. Review of medical physiology. $22^{\text {nd }}$ edition. New York: Lange/McGraw-Hill Companies; 2005. 315-335 p.

31. Bobe G, Ametaj BN, Young JW, Beitz DC. Effects of exogenous glucagon on lipids in lipoproteins and liver of lactating dairy cows. J
Dairy Sci. 2003;86:2895-903. DOI: $\quad 10.3168 / j d s . S 0022-$ 0302(03)73886-7.

32. Sai S, Chaurasiya M, Thakur SS, Kewalramani N, Kaur J. Performance of karan-fries calves as affected by supplementation of rumen protected methionine plus lysine and choline. Indian J Anim Nutr. 2016;33(1):27-32. DOI: 10.5958/2231-6744.2016.00005.0.

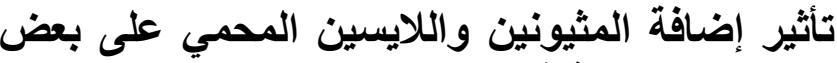 المعاييز الفسلجية في عجول التسمين}

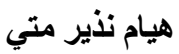

المرعل، الفسلجة والكيماء الحياتية والأدوية، كلية الطب البيطري، جامعة

أجريت هذه الدراسة خلال الفترة من شباط إلى نيسان 9 أب اب في

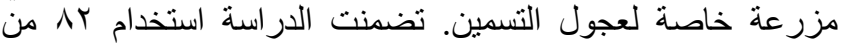

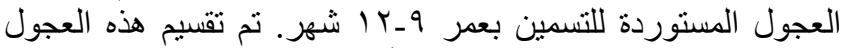

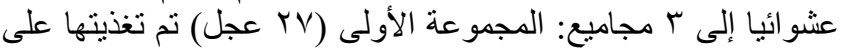

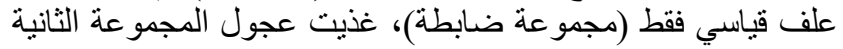

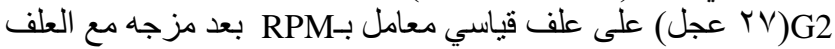

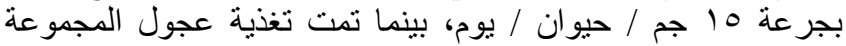

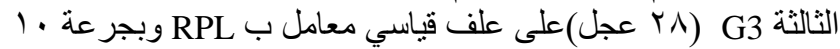

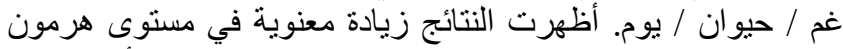

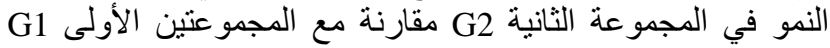

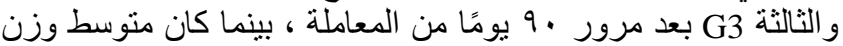

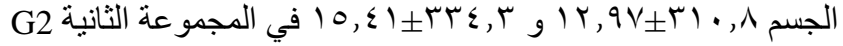

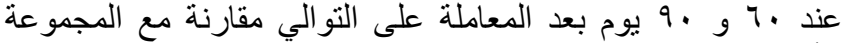

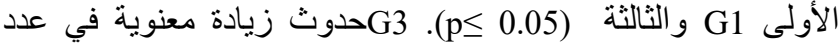

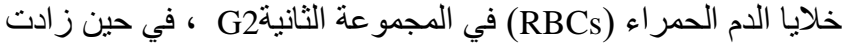

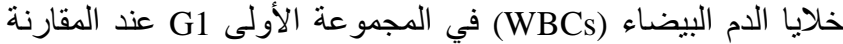
بين المجاميع ، وفي الاختبار ات الكيموحيوية كانت هنالك زيادة معنوية الأولية (P >0.05) في قيم الكوليسترول و والدهون الثلاثية في المجمو عة الثانية

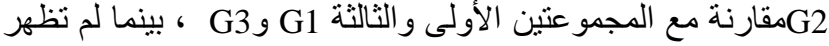

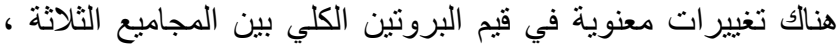

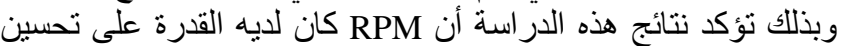

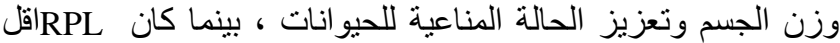
تأثير ا في بعض معايير هذه الدر اسة. 